\title{
BRIDGING THE MISSING LINKS IN THE IMPLEMENTATION OF TECHNICAL VOCATIONAL EDUCATION AND TRAINING CURRICULUM IN NIGERIA
}

\author{
Kagara, Abdul Bello* \\ Department of Industrial and Technology Education, \\ School of Science and Technology Education, \\ Federal University of Technology, P.M.B. 65, Minna. \\ Niger State - Nigeria. \\ abdulkagara@futminna.edu.ng

\section{Ibrahim, Dauda} \\ Department of Industrial and Technology Education, \\ School of Science and Technology Education, \\ Federal University of Technology, P.M.B. 65, Minna. \\ Niger State - Nigeria. \\ ibr.dauda@futminna,edu.ng

\section{Kareem, Wahab Bamidele} \\ Department of Industrial and Technology Education, \\ School of Science and Technology Education, \\ Federal University of Technology, P.M.B. 65, Minna. \\ Niger State - Nigeria. \\ wahabmi4u@futminna.edu.ng
}

*Corresponding author's Email: abdulkagara@futminna.edu.ng

Peer-review under responsibility of 4th Asia International Multidisciplinary Conference 2020 Scientific Committee http://connectingasia.org/scientific-committee/ (C) 2020 Published by Readers Insight Publisher, lat 306 Savoy Residencia, Block 3 F11/1,44000 Islamabad. Pakistan,

editor@ readersinsight.net

This is an open access article under the CC BY-NC-ND license (http://creativecommons.org/licenses/by-nc-nd/4.0/). 


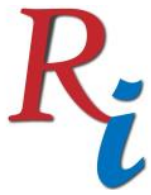

\section{Asia Proceedings of Social Sciences}

(APSS)

www.readersinsight.net/APSS

\section{A b s t r a c t}

The accomplishment of technical education curriculum implementation requires some level of government commitment because of it nature and important towards reducing unemployment. Technical vocational education is a skill acquisition intervention programs that target on erudite learning for wisdom that makes individual appropriate and creative in chosen field of technological and economic endeavor. To meet up with the $21^{\text {st }}$ century demand for the supplying of technology workforce the technical vocational education curriculum implementation in Nigeria must in totality be overhauled by ensuring that what is needed to achieve its goal is put in place for positive outcome. This paper discusses the philosophy of technical education towards job creation, the nature of technical education curriculum in institutions offering such program, the implementation of the curriculum of technical education and the factors that impede the implementation of technical education curriculum in Nigeria. It was concluded that TVET curriculum implementation faced a lots of challenges. Therefore, all stakeholders concern with the implementation of technical education within the sub-sector ought to put hands on together towards improvement of the implementation of technical education programs in Nigeria for better outcome.

\section{Research Heigh I ights}

1. Technical Education Curriculum

2. Technical Education Curriculum Implementation

3. Missing Links in the Implementation of TVET Curriculum in Nigeria

\section{Technical Vocational Education. and Training Curriulum}

Curriculum is the passageway to the growth of professional knowledge and skills which facilitate the flow from theory to practice (George, 2010). The major benefit of a technical vocational education curriculum are: (a) it focus only on students career training (b) it gives flexible programmes accessible from a multiple of sources and (c) provides training within many various areas that need technical skills rather than only academic experiences (Ellis, 2003). UNESCO (2009) defined curriculum as an sequences of organized learning experiences with the aim to generate definite, expected learning experience, and maintain that curriculum development are set of learning practices intended at introduces deliberate experiences in organize to achieve better outcomes from the learners. Hence, TVET curriculum is a skills acquisition experience and training which provides competence for career and employment opportunity. It was noted by Ogbonnaya (2009) that, in many school setting, gap exist between the intended and the learned curriculum and the author further explained that narrowing this 


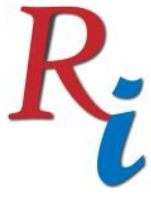

\section{Asia Proceedings of Social Sciences}

(APSS)

www.readersinsight.net/APSS

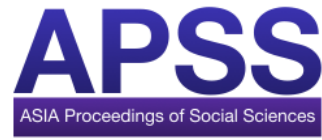

gap is ensure when there is effective curriculum implementation to a great extent to achieve the expected outcomes.

\section{Technical. Vocational Education. and Training Curriculum Implementation}

The implementation of TVET curriculum at classroom level encompasses a lot of ideas with required skills. Instructional activities must be properly plan for implementation to be effective in order to achieve the desired results within a time frame for the implementation. For instance, when the scheme merit is so excellent, but lacking a well-organized plan for implementation failure is the answer. UNESCO (2011) explained that implementation effectiveness of technical vocational education in Nigeria focuses on different fields that should be clearly understood concerning NBTE program blue print. The aspects upon which consideration is of concern for effective implementation are to understand clearly the demand of the trainee, end outcome state as well intervention expected in full.

The availability of infrastructural facilities and competent teacher should always be reviewed at a predetermine time to ascertain their influence on TVET curriculum implementation in Nigeria. The significance roles play by teacher in curriculum development, design and most prominently accomplishment cannot be over-emphasized. Even though teachers were expected to implement the curriculum they should be involved during policy formulation during review of curriculum to make it more robust. At the moment, technical vocational education curriculum in Nigeria is designed for implementation without sufficient manpower to transform these documents into actualization. Hence, implementation of technical vocational education curriculum is not free from hitches (Ayonimike, 2014).

\section{The Missing. Links in the Implementation. of TVET. Curriculum in. Nigeria}

Some of the challenges faced during the implementation TVET curriculum in Nigeria as observed by Egwu (2009) includes; limited and obsolete equipment and infrastructure, lack of standard libraries and workshop, decaying of blocks classroom, lack means of supporting structure for students industrial experience programme, brain drain on human capital flight, increase number of cultism cases, cheating during the examination and academic and social vices, frequently academic calendar changes, lack of qualify staff across board, lack of good teachers' conditions of service, insufficient fund and weak attitude collaboration among TVET institutions with other relevant organized private sectors.

\section{Conclusion.}

It was concluded that technical vocational education curriculum implementation in Nigeria suffered with many impediments which are tantamount with some of the problems of education 


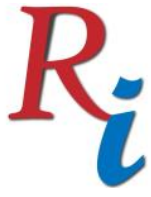

\section{Asia Proceedings of Social Sciences}

(APSS)

www.readersinsight.net/APSS

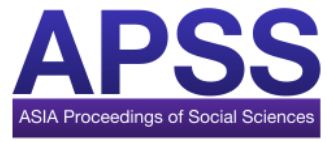

in Nigeria such as lack of professional teachers, poor provision of instructional materials, poor funding, and obsolete facilities for effective implementation. Therefore, it become very difficult to achieve the objectives of TVET due to implementation ineffectiveness within technical vocational education institutions in Nigerian, the government, nongovernmental organization, international organizational, and stakeholders should work assiduously to bridge these missing links in order to improve the implementation of TVET curriculum for poverty alleviation.

\section{References}

Ayonimike, C. (2014). Challenges in implementing the TVET Curriculum in Technical Colleges in Southern Nigeria; Makerere Journal of Higher Education 6(1) 87-97.

George S. M. (2010). The role of vocational education and training curricula in economic development. Procedia Social and Behavioral Sciences 2 3914-3920 www.sciencedirect.com Retrieved on 10/02/2020

Ogbonnaya, N. O. (2009). Social and political contexts of educational administration. Nsukka: Chuks Educational Publishers.

UNESCO (2011). Technical and vocational education and training. http://www.unesco.org/new/en/education/themes/education-building-bl. Retrieved on $10 / 11 / 2019$.

UNESCO (2009): The Worldwide Resource Pack for Capacity Building in Curriculum Development, An IBE Project.

Author's Biography

KAGARA, Abdul Bello holds Doctor of Philosophy (PhD and a Senior Lecturer in the Department of Industrial and Technology Education, Federal University of Technology Minna, Niger State - Nigeria. He is a member of Technology Education Practitioners Association of Nigeria (TEPAN) and Teachers Registration Council of Nigeria (TRCN). He authored and coauthored many research papers that were published in reputable national and international journals.

IBRAHIM, Dauda is a Lecturer at the Federal University of Technology, Minna. He is currently teaching in the Department of Industrial and Technology Education. He holds Doctor of Philosophy (PhD) from the Federal University of Technology, Minna. He is a member of Nigerian Institute of Building (NIOB), Technology Education Practitioners Association of Nigeria (TEPAN) and Teachers Registration Council of Nigeria (TRCN). He is married and blessed with five children. 


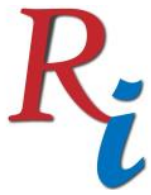

\section{Asia Proceedings of Social Sciences} (APSS)

www.readersinsight.net/APSS

KAREEM, Wahab Bamidele is a Senior Lecturer at the Federal University of Technology, Minna. He is currently teaching in the Department of Industrial and Technology Education, Federal University of Technology, Minna Nigeria. He obtained his Doctor of Philosophy (PhD) in 2017. He is a member of Technology Education Practitioners Association of Nigeria (TEPAN) and Teachers Registration Council of Nigeria (TRCN). He has published over forty articles in reputable journals and conferences. 